ISBN 978-93-84422-85-1

11th International Conference on Chemical, Agricultural, Biological and Environmental Sciences

(CABES-2018)

April 17-18, 2018 Kyoto (Japan)

\title{
Phytase Activity of Four Endophytes Bacteria from Zea Mays L.
}

\author{
Hafsan $^{1 *}$, Eka sukmawaty $^{1}$, Mashuri Masri ${ }^{1}$, Ahyar Ahmad $^{2}$, Laily Agustina ${ }^{2}$ and Asmuddin Natsir ${ }^{3}$ \\ ${ }^{1 *}$ Fakulty of Sains dan Teknologi, UIN Alauddin Makassar, South Sulawesi, Indonesia \\ ${ }^{2}$ Fakulty of Matematika dan Ilmu Pengetahuan Alam Universitas Hasanuddin, South Sulawesi, Indonesia \\ ${ }^{3}$ Faculty of Animal Science, Universitas Hasanuddin, South Sulawesi, Indonesia
}

\begin{abstract}
These research was a descriptive study that aims to describe the activity of phytase from endophytes bacteria isolated from Zea Mays L. Has been isolated and identified, four endophytes bacteria from Zea Mays $L$. ie. Burkholderia sp. strain HF.7 derived from root, Enterobacter cloacae strain HF.8 derived from stem, Enterobacter ludwigii strain HF.16 derived from leaves, and Pantoea stewartii strain HF.28 from seeds. The activity of phytase was known by measuring the absorbance value of the crude extract of phytase at $\lambda=700 \mathrm{~nm}$ which then analyzed the amount of phosphate content formed $(F T U / m L)$ in solution of crude extract of enzyme by substitution of absorbance value using linear regression equation of standard phosphate curve. The phytase activity of each endophytic bacteria was as follows: 7.83 FTU/mL; 5.24 FTU/mL; 6.34 FTU/mL; and 4.93 FTU/mL. Fourth endophytic bacteria of Zea Mays L. which indicates a relatively high phytase activity, was an opportunity to use it as a feed additive in order to improve the quality of poultry feed.
\end{abstract}

Keywords: Endophytes bacteria, phytase, phytat, Zea Mays L.

\section{Introduction}

The presence of phytate in broiler feed is a limiting factor in terms of feed quality. As an antinutrition that can't be hydrolyzed in the digestive tract of broiler so as to reduce the digestibility of minerals and proteins and the activity of digestive enzymes. This is related to phytate characteristic as the main form of phosphorus deposits in plants, has the ability as a chelator to bind proteins and ions of minerals such as calcium, iron, zinc, magnesium, manganese and copper [9]. For monogastric animals like broilers that have limitations in producing phytase in their gastrointestinal tract [6] and [2], the presence of phytate compounds may decrease the digestibility of phosphorus, as do other proteins and minerals in the feed because it can't be hydrolyzed in the digestive tract and or result in its availability becomes very low. Phytate can also form complexes with protein enzymes in the gastrointestinal tract causing a decrease in activity, and this can lead to a decrease in nutrient digestibility in general. To meet the needs of phosphorus broilers usually need to be added inorganic phosphorus such as dicalcium phosphate or monocalcium phosphate in the feed and consequently can lead to an increase in the amount of phosphorus is wasted with feces into the environment, and can simultaneously have implications for ecological damage, which is the result of eutrophication of waters [3].

Efforts to improve the efficiency of utilization of phosphorus and other minerals bound by phytate and reduce its negative influence on other nutrient utilization can be done by breaking the bonds through the hydrolysis process by phytase. Phytase is a phosphomonoesterase enzyme that can hydrolyze phytate into inorganic orthophosphate, mio-inositol and monophosphate, and free proteins and other bound minerals. The principle of phytase work for the purpose of nutrient utilization is by increasing the absorption of nutrients through the breaking of phytate compounds, so that minerals and proteins can be utilized maximally in the process of metabolism and biosynthesis [4]. 
Phytase can be obtained from various sources, these days have many derived from plants, fungi, bacteria or rumen of ruminants. Bacteria as a source of enzymes have more value than isolating enzymes from animals and plants, partly because bacterial cells are relatively easier and faster to grow and the conditions during production are independent of the changing seasons. In fact, the search for a superior source of enzymes such as fitters producing bacteria is very important to be a concern. This is related to the variation of enzyme characteristics produced by different sources, such as substrate specificity, catalytic efficiency and other physiological properties.

Endophytic bacteria as one of the unique bacterial groups that have natural habitat in plant tissue from root tissue, leaves and stems and seeds are very interesting to explore. Various secondary metabolites have been produced and studied, either as antibiotic compounds, antivirals, anticancer, antioxidants, antiinsecticides, and antidiabetics even as an antiimonosuppressive compound [10]. The ability of endophytic bacteria to produce phytase has not been widely reported, especially to be applied in improving the quality of broiler feed, so in this aimed to determine the ability of endophytes bacteria that have been isolated from Zea Mays L. in producing phytase.

\section{Methods}

\subsection{Isolation, Screening and Identification of Endophytic bacteria Zea Mays L. Phytase Producer}

Isolation of bacteria from Zea Mays organ tissue that has the ability to produce qualitative physiology includes the preparation of samples of root organ, stem and seeds aseptically. Bacterial selection was based on four isolates having the highest phytatic index on the selective phytase medium of each maize organ. The selected isolates, which show the highest capability based on IF, is the ratio between the diameters of the clear zone around the growing colony against the diameter of the colony. The isolates were then characterized by cell morphology and colonies, as well as Gram properties. Macroscopic observations include observation of size, pigmentation, shape, elevation, surface and margin/ edges of the colony. Microscopic observation was done by observing the cell shape and Gram properties through Gram staining. Subsequently, validation of the phenotypic identification has performed based on morphological, physiological and biochemical characteristics of selected isolates. This is necessary given the many similarities of biochemical and physiological properties possessed by different bacteria especially if it is a group of bacteria that have very close kinship. Selected isolates were identified molecularly with a gene analysis of 16s rRNA [12].

\subsection{Production, Isolation and Determination of phytase activity}

Phytase production begins with the determination of growth curve of selected bacterial isolates; the growth standard curve is made by measuring the Optical Density (OD) value of selected isolate cultures on the production medium at any time period. A total of three oses from each pure culture of selected bacterial isolates were inoculated in $50 \mathrm{ml}$ of medium. Suspended bacterial isolates were incubated in a shaker incubator with room temperature of $200 \mathrm{rpm}$ agitation. The OD value is measured every 2 hours with a spectrophotometer at $\lambda$ $=600 \mathrm{~nm}$ to obtain a series of OD using a turbidimetric method. The growth curve is the relationship between the values of OD to the incubation time.

Measurement of phytase activity, determined based on the ability of the crude extract phytases to hydrolyze the mioinocytol bond of the phytate as substract. Activity of phytase was determined by measure the absorbance values of the crude extract of phytase at $\lambda=700 \mathrm{~nm}$, then analyzed the amount of phosphate content formed (FTU/mL) in solution of of enzyme by substitution of absorbance value using linear regression equation of standard phosphate curve [1]. 


\section{Result and Discussion}

\subsection{Isolation, Screening and Identification of Endophytic Bacteria Zea Mays L. Phytase Producer}

The characteristics of selected isolates has done by macroscopic and microscopic observation. The results of Gram staining of the four selected endophytic bacterial phytase isolates showed Gram negative properties. In these bacteria, the main dye of violet crystals that form complex compounds with lugol gives the appearance of purple cells. The color is easily removed by washing using $95 \%$ alcohol solution, then colored by safranin as a second color so that it is red, is a Gram negative bacteria. Gram staining of other groups of bacteria, violet crystals and lugol as the main dyestuffs can remain strongly bonded after washing with $95 \%$ alcohol and will be purple and can't be stained by a second dye of safranin, a Gram-positive [8].

Based on the sequence similarity results from the four selected isolates with sequences contained in the bank gene showed that endophytic bacterial isolates from maize roots with HF.7 codes have in common up to $99 \%$ with 10 species of the Burkholderia genus registered in the NCBI database. Based on the highest total score score, there are three isolates showing the same value of 1493. This indicates that endophytic bacteria with HF.7 codes have genotypical similarities with Burkholderia lata, Burkholderia contaminans and Burkholderia cepacia species. Specifically, HF.7 isolates are not known as Burkholderia lata or Burkholderia contaminans or Burkholderia cepacia species, thus defining the endophytic bacteria, derived from maize root with HF.7 code as Burkholderia sp. strain HF.7. Isolate endophytic bacteria from stem with code HF.8 has 99\% similarity with Enterobacter cloacae. Endophytic bacterial isolates from leaf code HF.16 had 98\% similarity with Enterobacter ludwigii and endophytic bacterial isolate from seed code HF.28 had 97\% similarity with Pantoea stewartii subsp. indologenes.

\subsection{Production, Isolation and Determination of phytase activity}

Phytase production has begun by determined the bacterial growth curve. It is important to know the optimum phase of phytase production. The growth curve of four selected endophytes bacteria as in Fig. 1. The growth curve is the relationship between the values of (OD to the incubation time. The OD value was measured every 2 hours with a spectrophotometer at $\lambda=280 \mathrm{~nm}$ and obtained a series of OD using a turbidimetric method.

Generally enzymes are produced during bacterial growth and will achieve the highest activity at the end of the phase. The time has the basis for the length of incubation required as a starter, so the length of incubation required for the production of phytase is up to the end of the log phase which can be extended to half the stationary phase.

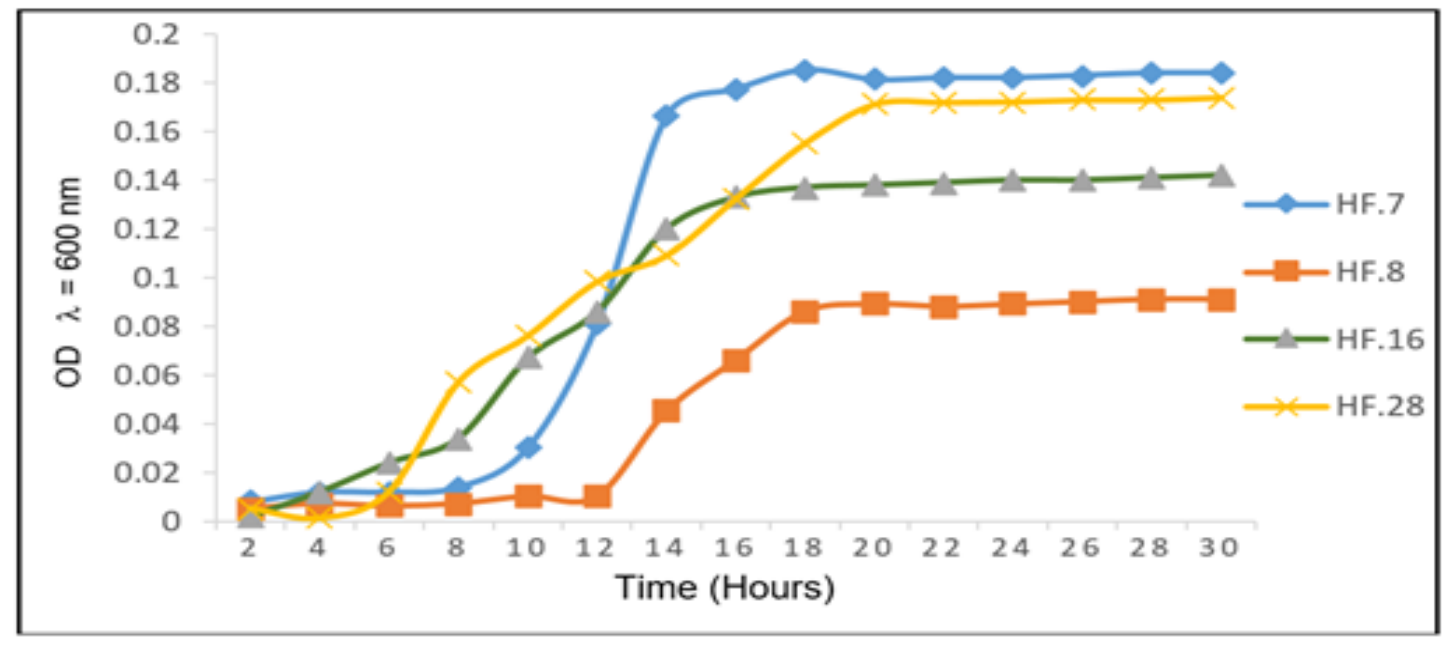

Fig. 1: Growth curve of four endophytes bacteria from Zea Mays L.

(HF.7) Burkholderia sp. strain HF.7; (HF.8) Pantoea stewartii strain HF.8; (HF.16) Enterobacter ludwigii Strain HF.16; (HF.28) Enterobacter cloacae Strain HF.28. 
Based on the growth curve of the four selected isolates, phytase production was performed by inoculating each $5 \mathrm{~mL}$ isolate starter culture suspension into $250 \mathrm{~mL}$ sterile production medium and incubated at $28^{\circ} \mathrm{C}$ with $18 \mathrm{~h}$ incubation time for HF.7, $18 \mathrm{~h}$ for HF.8, $16 \mathrm{~h}$ for HF.16 and $20 \mathrm{~h}$ for HF.28 used a shaker incubator at 100 $\mathrm{rpm}$. The culture was then centrifuged $5000 \mathrm{rpm}$ for $35 \mathrm{~min}$ at $4{ }^{\circ} \mathrm{C}$. The supernatant obtained by separation from its precipitates is crude phytase, then its activity is measured.

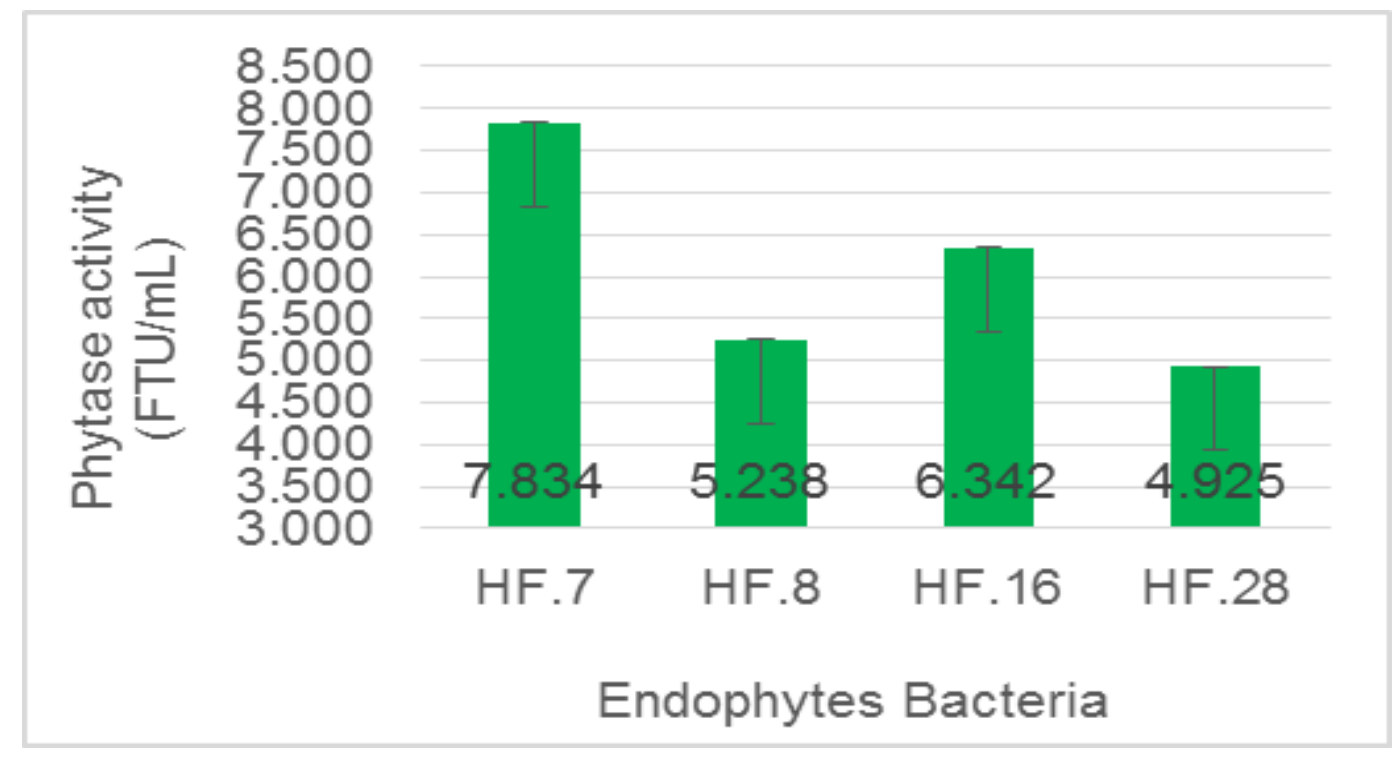

Fig. 2: Phytatse activity of four endophytes bacteria from Zea Mays L. (a) Burkholderia sp. strain HF.7; (b) Pantoea stewartii strain HF.8; (c) Enterobacter ludwigii Strain HF.16; (d) Enterobacter cloacae Strain HF.28.

The phytase activity produced by the four selected endophytic bacterial isolates ranging from 4.9-7.8 FTU/mL, showed higher activity compared with the activity of bacteria Burkholderia sp. the a13 strains were 4.1 FTU/mL, Bacillus cereus ASUIA 260 was 1.160 FTU/mL, and Bacillus subtilis AP-17 was 0.0296 FTU/mL [7]. Similarly, the phytase produced by three strains of Bacillus cereus isolated from Mount Merapi volcanic ash is $0.1071 \mathrm{FTU} / \mathrm{mL}, 0.1020 \mathrm{U} / \mathrm{mL}$ and $0.0874 \mathrm{FTU} / \mathrm{mL}$ [12]. Also has reported that phytase activity by Staphylococcus lentus ASUIA 279 of 1.913 FTU/mL [5]. Similarly it has reported, that the activity of three bacterial strains of Bacillus cereus bacteria isolated from water samples and Sikidang Dieng crater mud, ie $0.32893 \mathrm{FTU} / \mathrm{mL} ; 0.324953 \mathrm{FTU} / \mathrm{mL}$, and $0.32182 \mathrm{FTU} / \mathrm{mL}$ [11].

Fourth endophytic bacteria of Zea Mays L. which indicates a relatively high phytase activity, was an opportunity to use it as a feed additive in order to improve the quality of poultry feed. However, it still requires further research related to the complete profile of the characteristics of the phytases.

\section{Conclusion}

From Zea Mays L., can be isolated endophytic bacteria that have the ability to produce phytase with relatively high activity. Four endophytic bacteria obtained respectively from root, stem and Zea may L seeds were identified with phytase activity as follows: Burkholderia sp. strain HF.7 (7.83 FTU/mL); Enterobacter cloacae strain HF.8 (5.24 FTU/mL); Enterobacter ludwigii strain HF.16 (6.34 FTU/mL); and Pantoea stewartii strain HF.28 (4.93 FTU/mL). The tends to be high activity of phytase produced by the four isolates, potentially to be applied as feed additive to improve the quality of poultry feed. 


\section{References}

[1] N. M. K. El-Toukhy, A. S. Youssef, and M. G. M. Mikhail. 2013. Isolation, purification and characterization of phytase from Bacillus subtilis. African J. Biotechnol. 12: pp. 2957-2967.

[2] Greiner and U. Konietzny. 2006. Phytase for food application. Food Technol. Biotechnol. 44 (2): pp. 125-140.

[3] Y. Guo, Y. Shi, F. Li, J. Chen, C. Zhen and Z. Hao. 2009. Effects of sodium gluconate and phytase on performance and bone characteristics in broiler chickens. Anim. Feed Sci. Technol., 150: pp. 270-282.

https://doi.org/10.1016/j.anifeedsci.2008.09.006

[4] Hafsan, I. I. Irwan, L. Agustina, A. Nasir, dan A. Ahmad. 2017. Isolation and characterization of phytase-producing thermophilic bacteria from sulili hot springs in south sulawesi. SCIRJ. 5 (12): pp. 16-19.

[5] A. S. M. Hussin, A. E. Farouk, R. Greiner, H. M. Salleh, and A. F. Ismail. 2007. Phytate degrading enzyme production by bacteria isolated from malaysian soil. World. J. Microbiol. Biotechnol. 23: pp. 1653-1660.

https://doi.org/10.1007/s11274-007-9412-9

[6] L. A. Johnson, A. Deep and H. Classen. 2014. Digestibility and performance responses of broiler chickens fed a peabased diet with different levels of dietary microbial phytase. University of Saskatchewan Undergraduate Research Journal. 1 (1): pp. 39-44

[7] A. P Kusumadjaja, B. Tutuk, T. P. Ni Nyoman, dan Sajidan. 2009. Screening mikroorganisme termofilik penghasil enzim phytase yang tumbuh di kawah ijen banyuwangi”. Indonesian J. Chem. 9 (3): pp. 500-504. In Indonesian.

[8] M. T. Madigan, J. Martinko, and J. Parker. 2004. Brock Biology of Microorganisms (10 ${ }^{\text {th }}$ Edition). Lippincott Williams and Wilkins. USA.

[9] E. M. Onyango, M. R. Bedford and O. Adeola. 2005. Efficacy of an evolved Escherichia coli phytase in diets for broiler chicks. Poult. Sci. 84: pp. 248-255.

https://doi.org/10.1093/ps/84.2.248

[10] S. Radu and C. Y. Kqueen. 2002. Preliminary screening of endophytic fungi from medicinal plants in malaysia for antimicrobial and antitumor activity. Malays. J. Med. Sci. 9 (2): pp. 23 - 33.

[11]E. N. Sari, Sajidan, dan Sugiyarto. 2013. Identifikasi bakteri penghasil phytase dan karakterisasi phytase dari kawah sikidang dieng. El-Vivo. 1(1): pp. 112-115.

[12]R. Wulandari. 2015. Analisis gen 16S rRNA pada bakteri penghasil enzim phytase. Tidak diterbitkan. Thesis. Universitas Sebelas Maret. Surakarta. In Indonesian. Unpublished. 